\title{
VILNIUS and the PROBLEM of MODERN LITHUANIAN STATEHOOD in the EARLY TWENTIETH CENTURY
}

\author{
Rimantas MIKNYS \\ Lithuanian Institute of History
}

In the interpretation of Lithuanian intellectuals and politicians of the early 20th century, Vilnius and the region of Vilnius (Eastern Lithuania), actually comprising Catholic Byelorussia as well, culturally and ethnographically was, and presumably has remained up to this day, a distinct territory. The well-known scholar, thinker and cultural figure Mykolas Römeris distinguished four main population groups in that territory - Byelorussians and Lithuanians, living together in a fairly close relationship, autochthonous Poles, living in bigger or smaller enclaves , and lastly, the Jews, scattered throughout the region. ${ }^{1}$ The local Polish community considered a result of particular historical circumstances. It is worth noting that by their psychical, ethnical and cultural traits they were intimately integrated into local society and differed markedly from the Poles of the ethnic Poland. In the words of Römeris, the most numerous stratum of that population, however, consisted of tutejszi, the people, representing a Balto-Slavonic multilayered linguistic and ethnic mixture of a peculiar psyche.

The cradle of the statehood and culture of old Lithuania was Vilnius. The state, however, could only rather ephemerally safeguard the coexistence of diverse national cultural elements - Lithuanians, Poles, Jews, Byelorussians, and lastly Russians, because only a very narrow social stratum was represented by civic society - aristocracy and gentry - and their national and cultural orientation was determined by a particular development of Lithuanian statehood, affected by the Lithuanian-Polish union.

In the nineteenth century under the conditions of Russian oc-

'M. Römer. Stosunki etnograficzno-kulturalnie na Litwie. Kraków, 1907, 10-13; M. Römer, E. Römer-Okhenkovskaia. Poliaki i formy natsionalnogo dvizheniia v sovremennykh gosudarstvakh. St Petershurg, 1910, 364-365. His version of the autochthonism of Lithuanian Polcs is presented by Römeris in detail in his 1933 article. 'Dwie teorie o polakach litewskich'. Kurjer Wilenski, October 10, 1994. With some reservation, the situation can be illustrated by the data of the 1897 census of the Russian Empire, according to which Jews made up $40.1 \%$ of the population of Vilnius, Poles $-31.0 \%$, Russians $-20.1 \%$, Byclorussians $4.2 \%$ and Lithuanians $-2.0 \%$. Pervaia vseobshchaia perepis naseleniia Rossiiskoi imperii, 1897. IV. Vilenskaia guberniia, tetr. 3, 1903, 124-125. 
cupation and oppression those national cultural elements had no common civic ground. Differences between them deepened and they further isolated themselves in ethnic communities. The antagonism between Lithuanian and Polish elements became apparent in the development of national movements. The Lithuanian movement, whose most conspicuous representative was the periodical Aušra, displayed the influence of the Lithuanian national cultural element as the prime factor in the processes of integration of the modernization of the traditional society with the formation of the new one. First and foremost, the movement was interested in the protection and elaboration of Lithuanian culture and national identity. Meanwhile, the Lithuanian aristocracy and the majority of the gentry, who identified themselves with the Polish cultural tradition, still cherished hopes of union with Poland. They regarded the appearance of the Lithuanian movement as dangerous. In the words of Römeris, a number of the representatives of the old civic society did not trust the cultural potential of the Lithuanian people for restoring and cultivating its statehood and forming a new civic society. For this reason they doubted the perspectives of the movement. On the other hand, they protected their privileged status adamantly and were unwilling to share civic and political rights with the "common people". In their judgement the 'people' and 'society' were mutually exclusive concepts. The Lithuanian democratic national movement was unacceptable to them in its essence. ${ }^{2}$

In general, Polish politicians treated the Lithuanian movement as a Russian 'intrigue' in the solution of the Polish problem, oriented towards weakening moves to restore statehood. ${ }^{3}$ It must be noted that such a viewpoint was not without foundation. ${ }^{4}$ After the uprising of 1863-64, the discriminatory policy of Russia towards the gentry weakened their social influence and role in cultural life under the conditions of the Lithuanian movement, and they found themselves somewhat peripheral to that society. The new situation intensified their orientation towards Poland in their search for social, cultural and political affinity and support. All that in its turn strengthened the dis-

\section{${ }^{2}$ M. Römcr. Stosunki ...20-22.}

${ }^{3}$ P. Lossowski. Po tej i tam tej stronie Niemna. Warszawa, 1985, 23-25, 28.

${ }^{4}$ In 1883 a kcy figure of the Lithuanian national movement Jonas Basanavičius, on tactical grounds, published scveral articles in a pro-government newspaper Novoe vremia, in which he dissociated himself from the Poles in his attempts to obtain a permission for the Lithuanian press. He characterized the necessity of Lithuanian publications in Roman script as a means of frecing ordinary Lithuanians from Polish cultural influence and making them obedient subjects of Russia. One of the editors of Aušra, Jonas Šliūpas, also flirted similarly with the Russian government with the same aim in view. In 1884 he sent a memorandum to the governor-general of Warsaw, Iosif Vladimirovich Gurka, arguing that the lifting of the Lithuanian press-ban would be useful to the Russian authorities as a way of weakening the Polish influcnce in Lithuania, scparating local intelligentsia from Poland and strengthening the moral tics of the Lithuanian people with Russia. The results of those actions, however, were not effective. 
trust of Lithuanian intellectuals, with which they viewed the aristocracy and gentry and the Polish national movement, sometimes favouring even chauvinistic ideas. ${ }^{5}$ Severe Russian chauvinism also channelled the Lithuanian national movement into a narrow nationalistic course. In that vicious circle the growth of external and internal confrontation between the Lithuanians and the Poles was inevitable.

The conflict intensified in the early 20th century, when the Lithuanian national movement entered a phase of political development. The first Lithuanian political parties - the Lithuanian Social Democrat Party (LSDP) (1896) and the Lithuanian Democrat Party (LDP) (1902) - formulated in their programmes the aim of political independence of Lithuania in its ethnographic boundaries. In order to ensure the legality of that aim, a representative forum of the Lithuanian population was convened in 1905. This is known as the Seimas (the Great Assembly) of Vilnius, and in scholarship, as the Great Seimas. In regard to the political autonomy of Lithuania, the declaration adopted by the Seimas proclaimed: "That autonomous Lithuania must consist of the present-day ethnic Lithuania as the heartland and of those areas, which, due to economical, cultural, national or other reasons, gravitate towards that heartland and the inhabitants of which wish to belong to it ...". "The resolution, as well as the programme objectives of the parties markedly emphasized the national democratic nature of the future modern state of Lithuania. After the First World War that state, like Poland and certain other Central-and EasternEuropean states, was to be based on the principle of the national (ethnical) sovereignty and the representation of the anonymous majority rather than on the principle of the populus (political nation). ${ }^{7}$ Actually, that meant the perspective of a sociocratic state, based on nationalism. In the creation of the state the initiative had to belong solely to the ethnic nation - the Lithuanians.

Paradoxically, that theory exploited the historical legal heritage of old Lithuania - the Grand Duchy of Lithuania - the legacy of the state, which was the motherland not of one, but of several modern nations, having evolved (or still evolving) from the above-mentioned

${ }^{5}$ That was most clcarly manifested in the programme of the ND (Narodowa

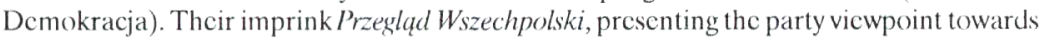
the Lithuanians and the Byclorussians, declared an intent to foster the 'tribal consciousness' (świadomość plemienna) of the latter, also accentuating that the lands, inhabited by the aforementioned nationalitics, were Polish both from the historical and legal vicwpoints. In 1903 spccifying their position on the Lithuanian national movement, the ND characterized it as a 'natural and useful' phenomenon, stressing the political necessity of that movement to unite with the Polish nation; sce P. Lossowski. Po tej, 49-50.

${ }^{6} \mathrm{~J}$. S-lius |Basanavičius, Jonas - hercafter the proper names in squarc brackets stand for the real names of the writers|. Iš didžiojo Vilniaus seimo istorijos. Vilnius, 1925, 20. On the programme objectives of the above-mentioned partics in greater detail, sec R. Miknys. Lietuvos demokratu partija 1902-1915 metais. Vilnius, 1995.

${ }^{7}$ M. Römcris. Lietuvos konstitucines teises paskaitos. Vilnius, 1990, 39-46. 
national cultural elements. In Römeris' words, those issues meant the proviso of Lithuanian statehood or that of modern Lithuania. ${ }^{8}$ Regrettably, they also formed the essence of the Vilnius Question.

As far back as 1905 Römeris had noted: "At present Vilnius is already a bone of contention among several nations"." In particular, he stressed the traditional competition and confrontation between the Polish element and the regenerating and rapidly evolving Lithuanian element. And that observation was not accidental, because the contemporary situation in Russia had become comparatively rather liberal (that was very unusual for the empire), enabling a frank discussion of the political independence of Poland and the old lands of the GDL. That led to increased confrontation and to the accentuation of the Vilnius question.

It should be noted that between the opposing Lithuanian and Polish sides there appeared political forces, who realized the danger of the nationalistic clash for the solution of the problems of the Lithuanian and Polish political independence and of Vilnius and sought some consensus of opinion in formulating the conception of modern Lithuanian statehood. It is worth investigating these issues from the perspective of our times and to arrive at conclusions which might be relevant to the solution of present-day problems, in the first place, of the Polish ethnic minority in Vilnius and the surrounding region.

The issues relating to the year 1905 have been extensively dealt with by scholars, ${ }^{10}$ and here an analysis of their essence should suffice. At the end of 1904 and the beginning of 1905, preparations were made for the discussion of Polish autonomy at the congresses of the zemstvo activists - the forums, organized by the Russian Liberals. In Vilnius attempts were made to include the question of Lithuanian autonomy, too, thus stressing the topicality of the political problem of the lands of the old GDL, which had to be solved, in any case, in addition to the Polish question. Efforts were also made to present the problem of autonomy on behalf of the population of Lithuania. 'The LithuanianPolish Irredentist Circle', set up in December 1904, presented their request in the following wording: "We demand that the Russian constitution be based on a free federation of those countries (in their ethnographic boundaries), the population of which declare the individuality of their nation and require autonomy (Lithuania, Poland, Finland, the Ukraine). "The members of the Circle - the democrati-

${ }^{8}$ Ibid., 42.

"M.Römer. Stosunki, 9.

${ }^{10}$ M. Römcr. Litwa. Studyum o odrodzeniu narodu litewskiego. Lwów, 1908, 349-354; M. Römer, E. Römer-Okhenkovskaia. Poliaki. 375; J. Jurkiewicz. Demokraci Wileńscy w latach 1905-1914 / Zarys działalności polityczncj. Acta Baltica-Slavica, t. XV, 1983, 162; R. Miknys. Lietuvos demokratu partija, 79-91.

"P-tis [Jonas Vileišis]. Lictuviụ ir lenkų irridentų kuopa (The Lithuanian-Polish Irredentist circle). Varpas, nr. 1/2, 1905, 2-3. 
cally minded Polish and Lithuanian public figures of Vilnius reached a kind of compromise through that wording.

In the Circle the Lithuanians were represented by the Lithuanian Democrats of Vilnius Povilas Višinskis, Jonas Vileišis, Felicija Bortkevičiene and Antanas Smetona, who advocated restoration of ethnic Lithuanian statehood and propagated the ideas of the formation of a democratic society. The Polish side was represented by the intellectuals of Vilnius Tadeusz Wróblewski, Ludwik Abramowicz, Jan Klott, Bronisław Krzyźanowski, Józef Bukowski. In one way or another, these were associated with that section of Polish society of Lithuania, which still cherished the self-awareness of the citizens of the GDL and treated the territory of Lithuania and Byelorussia as an indivisible political, economical and cultural entity. Accordingly, they defended the prospect of restoring the old Lithuanian (Byelorussian and Lithuanian) statehood. They regarded the emergence of Lithuanian and Byelorussian national movements favoruably and as regarded the state, they were in favour of the cooperation of the national groups, living in the country (Lithuania and Byelorussia). Taking into account the possibility of the isolation due to the rise of modern Lithuanian democratic society, These representatives of the Polish society in Lithuania wanted the Polish public of Lithuania maintain its cultural national ties with Poland and on the principle of citizenship enter the newly developing socio-political formation in the territory of the old GDL as an equal member. Thus, the common aspirations in the formation of democratic society led to compromise solutions. It is also noteworthy that the terms 'Lithuania', 'the land of Lithuania', used in the other places of the document, somewhat neutralized the ethnographic principle, indicated in the main article. The very concept of ethnic Lithuania under contemporary circumstances did not contradict the prospect of historic Lithuania. Such boundaries of Lithuania, in essence, coincided with those of its historical heartland. ${ }^{12}$

The representative of the Circle, Wróblewski, presented the compromise requests to the participants of the zemstvo congress, which took place in Moscow on April 9-13 (22-26 new style) 1905. However, in contrast to the actively debated question of the Polish autonomy, the Lithuanian issue did not attract any greater attention. ${ }^{13}$

Seeking to prepare a more solid legal and political background for the dispute on the autonomy, a congress of the representatives of

${ }^{12}$ Römeris has indicated that the border with Latvia was marked along the traditional cultural, cconomical, historical and national linc; in delimiting the boundary with Poland the national principle in the counties of Scinai and Suvalkai was taken into account. The border with Byelorussia approximately coincided with the boundaries of the counties of Vileika and Dysna, and a part of the province of Gardinas beginning with its middle west and the county of Naugardukas of the province of Minsk. Scc M. Römer. Litwa ..., 395 397.

${ }^{13}$ R. Miknys . Op. cit. , 83. 
the peoples of Lithuania was convened by the Circle on April 22 (May 4). However, its participants - Lithuanians (both LDP and LSDP representatives), Poles, Byelorussians and Jews - did not adopt any joint resolution, owing to the differences of opinion. The Lithuanians defended the concept of ethnic Lithuania, while the others supported the idea of historic Lithuania. ${ }^{14}$

A more detailed discussion of the viewpoints took place on May 19-21 (June 1-3), when the members of the Congress met again in order to reach a consensus. Lithuanian representatives had to justify the separation of Byelorussia from ethnic Lithuania. In principle having nothing against Byelorussian autonomy and recognizing the autonomy right of the peoples and territories, possessing separate cultural, economical and social structures, the Lithuanians maintained that the realization of that right depended on the self-consciousness of that particular population. In their opinion, Byelorussian intellectuals at the congress did not represent their people, which had not yet 'awoken'. Therefore, their claim to autonomy was illogical, as it did not naturally originate in the process of national rebirth. ${ }^{15}$ Doubtless, the Lithuanians had enough arguments to defend their viewpoint. After an analysis of those processes, Römeris stated that the Byelorussians had not yet overcome the obstacles on their way to the formation of their nation, and that they were rather heterogeneous economically and culturally in their ethnographic territory. ${ }^{16}$

In contrast to the situation in Byelorussia, Lithuanian political autonomy had to put the final touches to national consolidation, the natural stage of its cultural development. In that process, the ethnographic concept defended at the congress, seemed least fraught with complications. The alternative choice - the concept of historic Lithuania - would have placed the Lithuanians in the position of a national minority, and that in its turn would have changed its role as an ethnical nation in the formation of the political nation. There were serious doubts as to whether the contemporary weak Lithuanian culture would not be able to resist the Polish variety of culture of the GDL, which had both age-long traditions and potentially favourable conditions for further expansion. The second conception was even treated as creating danger for the very existence of the Lithuanian nation.

Simultaneously a group of Byelorussian intellectuals, exploiting the concept of historic Lithuania, strove for joint LithuanianByelorussian autonomy (the provinces of Vitebsk, Grodno and Mogilev and the counties of Vileika and Dysna is the province of Vilnius were considered as the constituent parts of the then Byelorussia). In that

${ }^{14}$ Ibid., 84 .

${ }^{15}$ Ibid.

${ }^{16}$ M.Römer. Litwa ..., 349. 
way the Byelorussians intended to dissociate themselves from the Russian and Polish cultural influence and with the help of the reviving Lithuania to awaken the national self-consciousness of their own people.

The Poles and Jews of Lithuania and Byelorussia, politically (as citizens) not yet associated with the Lithuanian people, preferred the alternative of the political autonomy in historic Lithuania. The democratically-minded Polish intellectuals of Lithuania were oriented towards historical law, considering it as a more weighty argument than the nation's right of self-determination for the realization of the Lithuanian political autonomy, in particular, for submitting that issue for official political debate. In their opinion, the historical and cultural traditions of the GDL, its common economic life and rudimentary civic awareness of the Grand Duchy, supported by new democratic principles of government, had to ensure normal existence and evolution of all the nations in the country. Doubtless, the Polish element of the old GDL lands most tangibly perceived the homogeneity of the territory and, as well as the Jews, they made up an indivisible national entity. That stimulated their search of new arguments for the realization of political autonomy of historic Lithuania. ${ }^{17}$

It is only natural that the issue of Vilnius evolved in this debate. It was the Byelorussians who raised it in defending their situation. Basing themselves on the linguistic situation of Vilnius and its environs as, in their words, most favourable for them, they argued that in the context of the concept of historic Lithuania Vilnius belonged to Byelorussia. ${ }^{18}$ That was a kind of forewarning that in the solution of modern Lithuanian statehood the issue of Vilnius could not be ignored, and that at least the Lithuanian side had to be prepared for it.

Despite the decision of the congress to convene a constituent assembly in Vilnius 'on behalf of the entire population of Lithuania and Byelorussia' to discuss the relations between themselves and in regard to Russia, those issues were no more discussed in any greater detail.

In theoretical terms, the search for the solution of the Vilnius problem was continued together with the exploration of the way to Lithuanian statehood. The search was complex, because it led to the rise of overt confrontations between the Byelorussians and the Lithuanians and between the Lithuanians and the Poles. The struggle for the Polonization versus Lithuanization of Vilnius started in churches and in the press. The vehemence of the struggle can be illustrated by the following categorical statement of the Polish Democrat Ludwik Abramowicz: "... the Jews and the Russians aside, Vilnius is a purely

${ }^{17}$ Ibid., 349-352; Miknys, R. Lietuvos demokratu partija, 85-86.

${ }^{18}$ Römcr, M. Litwa ..., 352. 
Polish city. $\langle\ldots\rangle$ the Lithuanians are willing to consider Vilnius the centre of their motherland and cannot reconcile themselves to the changes brought by the centuries... collecting statistical material on the Poles in Lithuania would be better than high-sounding phrases. After all, numbers are so eloquent ... ". 19 A typical response to such observations would be the remarks of the well-known Lithuanian public figure Antanas Smetona: "Vilnius is the cornerstone of Lithuanian life. It can also be a Byelorussian centre. We shall never wrangle over Vilnius with the Byelorussians, we shall be able to coexist, because none of us harbour any aggressive ambitions. The Poles are different; they were and still are aggressors. They have driven out the Lithuanian language from the Lithuanian churches, and when the Lithuanians require its return, they are declared chauvinists and imperialists". ${ }^{20}$

Common-sense voices, nevertheless, could be heard among those mutual reproaches, too. Probably the most rational solution of the Vilnius issue was offered by Römeris in the same year. The essence of the problem was expressed in his thesis, maintaining that "the task of the nearest future is to put into effect the coexistence of the national and cultural elements of the region and of Vilnius on the basis of a joint civic precept, without endangering anybody's national and cultural identity; the Polonization of the Lithuanians and the Lithuanization of the Poles would be equally detrimental from the cultural point of view. ${ }^{21}$ In his attempts to avoid the clash of Polish and Lithuanian nationalisms, he proposed that scheme of coexistence in the framework of the re-establishment of Lithuanian statehood in its historic boundaries, and he intended to realize it in his activity.

Editing his Gazeta Wilenska, he developed a theoretical background for his concept - the ideology of the krajowcy. This system of ideas and viewpoints laid stress on the integrity of historic Lithuania, conditioned by the historical, territorial, economic and cultural similarities. The predominance of the interests of any particular nation in that region was condemned as prejudicial to the affairs of the other nations. ${ }^{22}$ Between 1906 and 1914 he recruited supporters of these ideas among the democratically minded Lithuanian, Lithuanian Polish, Byelorussian, Jewish and Russian intellectuals. Here the following representatives of the LDP and LSDP could be mentioned: Jonas Vileišis, Mykolas Sleževičius, Andrius Bulota, Mykolas Biržiška, Felicija Bortkevičienè, Augustinas Janulaitis, Jurgis Šaulys; the Poles of Vilnius Ludwik and Witold Abramowicz, Bronisław Krzyżanowski, Kazimierz Okulicz, Mieczysław Niedziałkowski; the Byelorussians Aleksandr

${ }^{14} \mathrm{~L}$. Abramowicz. Wolnc głosy w sprawic litcwskicj. Kwestya litewska w prasie polskiej. Warszawa, 1905, 47-48.

${ }^{20}$ A.Smctona. Rinktiniai raštai. Kaunas, 1990, 325.

${ }^{21}$ M.Römcr. Stosunki ..., 15-16.

22[M.Römcr| Editorial. Gazeta Wileńska, 190602 15/28, nr. 1. 
Zostavt, Vaclav Lastouski, Ivan and Anton Lutskievich; the Jews Jurgis Rom, Mojsiej Bramson, Cemak Šabad, Čarn, et al. Attempts were made to direct their activity not only towards fostering the ethnically and culturally varied national self-awareness of the people of historic Lithuania, but also towards stimulating the perception of the country's integrity among its population. ${ }^{23}$ Organizational contacts with democratic public figures were strengthened with that aim in view. Support was extended to the newspaper Przeglad Wilenski, which was to continue the ideological orientation of Gazeta Wilenska. When that initiative failed, support was switched over to the Byelorussian democrats, who started to publish their newspaper Kurjer Krajowy in 1912. The activity of the Vilnius lodges of Masonry ('Jedność', established in 1909, 'Litwa' - 1911, 'Białoruś' - 1914) was exploited, too..24

The most characteristic stage of those campaigns was the conferences of the democratic public figures of Lithuania's nations between December 1913 and February 1914, when attempts were made to set up a Lithuanian section of the Union of Autonomists and Federalists, re-established in Moscow at that time. That had to be done with the same intention of achieving Lithuanian political autonomy. ${ }^{25}$ The activity of the Section had to be aimed at achieving political autonomy, favourable for Lithuania and at accordingly preparing the Russian public opinion. It is noteworthy that there were no open references to the re-establishment of Lithuania as an independent state. Nevertheless, the slogan of autonomy was unequivocally identified with that of independence. Before the outbreak of the war two tendencies became evident in the Lithuanian right-wing groupings: The Christian Democrats were known as Germanophiles, looking forward to the defeat of Russia, while the National Democrats were not unanimous in their orientation. Some of them shared the Germanophile views of the Christian Democrats; the others associated the political independence of Lithuania and its unification with Lithuania Minor with the victory of the Russian tsar. Germanophile tendencies were also popular among the Social Democrats. The LDP least of all placed their hopes in the Russian and German states, and the idea of Lithuanian independence was most attractive to its members. Without explicitly declaring their orientation, they initiated the formation of the Lithuanian 'Autonomist' Section, themselves becoming its nucleus. They anticipated a victory of the Russian democratic revolution, which, in its turn, would enable the realization the political and social aspira-

${ }^{23}$ M .Römer. Dziennik. MAB MS: t. 3, F. 138-2230, 1. 62-63.

${ }^{24}$ R. Miknys. Mykolo Romerio pažiūris ị Vilniaus problemą. Lituanica, nr. 4(20), 1994, 28-29.

${ }^{25}$ M. Römcr. Dziennik, t.3, 1. 334, 352; t. 4, f. 138-2231, 1. 20-21. That union was established in Petersburg on 19-21 November (2-4 January) Attempts were made to realise its ideals by a paraparty 'Autonomist circle' in the First and Second Dumas. 
tions of the subjugated peoples. ${ }^{26}$ On the other hand, the Polish democratic intellectuals, on the initiative of Römeris, analyzing the possible variants of Lithuanian independence, proposed the formation of a joint Lithuanian-Byelorussian section and in November 1914 - February 1915 suggested a common agreement concerning the ways of re-establishing Lithuanian statehood. ${ }^{27}$ However, differences of opinion on the primacy of the concept of autonomy (historic or ethnic Lithuania) prevented both the establishment of the above-mentioned section and the adoption of any agreement for joint action.

In all those debates the Lithuanian side persistently held on to the decisions of the Great Assembly. Meanwhile, the pioneers of the Byelorussian national movement were antagonistically disposed towards the Lithuanian conception of the ethnic state and instead of it proposed the concept of historic Lithuania. The main argument in the defence of their position was the issue of Vilnius. They protested against the inclusion of Vilnius into ethnic Lithuania and denounced the attempts of the Lithuanians to treat Vilnius as their exclusive capital. They argued that "Vilnius is a historic, natural and up to the present day a live centre of the entire region of the whole ancient territory of the Grand Duchy of Lithuania, in actual fact, belonging equally to both Lithuania and Byelorussia, besides ... Vilnius is not at all situated in the Lithuanian ethnical territory, not even in the linguistically ethnical area, it is not inhabited by Lithuanians". ${ }^{28}$ To quote Römeris, "Vilnius ... serves as a starting point for the Byelorussians in their struggle and criticism of the Lithuanian conception of autonomy". ${ }^{29}$

The Lithuanian concept was subjected to an even harsher Byelorussian criticism for its treatment of 'the issue of outlying regions'. In it they saw Lithuanian expansionist aims and a scheme to divide Byelorussia into the western Catholic and the eastern Orthodox part, leaving the latter in the sphere of Russian influence and Russification. In their eyes, the realization of the conception of historic Lithuania was fraught with a greater danger than the Polonization or even Lithuanization of western Byelorussia. ${ }^{30}$ It must be noticed that such intentions were easy to detect in the statements of both Polish and Lithuanian politicians, in particular with regard to the projects of 'national enlightenment' of the tutejszi, a layer of the population, so far nationally unconscious, yet linguistically close to the Byelorussians. ${ }^{31}$ On the one hand, they were 'compensated' by the belief that elements,

${ }^{26}$ Litwa wobec wojny (Poufny memorial Michała Römera z sicrpnia 1915). Zeszyty Historiczne, zesz. 17 (Paris, 1970), 105-107.

${ }^{27}$ M. Romcr. Dziennik, t. 4, f. 138-2231, 1. 301, 303, 306, 371, 373.

${ }^{28}$ Ibid., 299.

${ }^{20}$ Ibid.

3"Ibid., 299, 300, 301, 303, 306.

${ }^{31}$ Ibid., 300. 
associated with western Catholic culture, per se fostered national feeling (that meant the development of Byelorussianness) in contrast to the elements of Byzantine culture. On the other hand, the emerging idea of the re-establishment of a renovated modern Jagiellonian state raised some hopes of avoiding that danger.

In the course of the debates Römeris exploited that idea in the elaboration of the statehood concept of historic Lithuania. The essence of the concept was the association (federation, confederation, union) of two independent democratic states (Poland and historic Lithuania), ensuring the preservation of both states under complicated geopolitical conditions (between Russia and Germany) and guaranteeing in the first place their political independence from Russian rule..$^{32}$ The democratic nature of such an association had to eliminate or at least weaken the manifestation of nationalistic tendencies.

The real course of events, however, destroyed such projects. Römeris' colleagues, the Polish Democrats of Vilnius Bronisław Krzyżanowski, Wytold Abramowicz, Zygmunt Nagrodzki, Wacław Studnicki, Jan Kłott, Stanisław Bagiński, Kazimierz Ostachiewicz et al., vigorously defended the Byelorussian position and criticized the Lithuanian theory of 'outlying regions'. In the first place, they were interested in the realization of national interests and their national idea to strengthen the Polish position in the country. ${ }^{33}$ Nevertheless, after prolonged and heated debates Römeris and Mieczysław Niedziałkowski ${ }^{34}$ managed to convince the participating Lithuanians that the restoration of their independent state was also possible in a democratic alliance or union with Poland, which was rated as an effective political subject in the contemporary international arena (the same could not have been said about Lithuania at that time). Taking that situation into account, Bortkevičiené, Šaulys ${ }^{35}$ and Sleževičius, actually representing the LDP, did not reject outright that third road of the restoration of Lithuania's statehood. After acrimonious discussions they agreed to carry on talks on that issue with the Warsaw representatives of the Polish independence movement. To quote Römeris, "The Lithuanians were eager to carry on talks, considering them useful, though actually they did not demonstrate any willingness for a joint German-biased action in the struggle for Lithuanian-Polish independence It was very obvious that the Lithuanian-Polish negotiations in Warsaw differed greatly from those conducted here between the Lithuanians and the local Poles. In the latter case emphasis was laid on common citizenship issues in the context of the Lithuanian problem, while the Warsaw meetings were talks of the representatives of

${ }^{32}$ Ibid., 334,347

${ }^{33}$ Ibid., 303.

${ }^{34}$ Ibid., 333, 334, 347, 367 .

${ }^{35}$ By that time Jurgis Šaulys had officially left the LDP. 
independent nations" ${ }^{36}$ Thus, in order to place the issue of Lithuanian statehood on the international level, the search for the achievement of independence was sort of postponed for some later date. That raised the hopes of the democratic Poles and Byelorussians of Vilnius for the realization of their conception. However, it soon became evident that that was hardly feasible.

On March 23-24 1915 the first consultative meeting of the Lithuanian and Polish political activists took place in Warsaw on the initiative of the local lawyer Stanisław Patek and the editor of Zarania Władisław Malinowski. The Polish side consisted of the representatives of the Btok Niepodlegtościowy and the Unia Ruchu Niepodległościowego Rafał Radziwiłowicz, Zygmunt Chmielewski, Stanisław Thugut et al.; the Lithuanian side was represented by M. Sleževičius (LDP), the non-aligned Democrat J. Šaulys, the Polish Democrat W. Abramowicz, and M. Römeris. An agreement was made to develop the established contacts and to set up information bureaux in Warsaw and Vilnius for further consultations. ${ }^{37}$ In Vilnius a bureau was not established. The LDP did not refuse to participate in the talks in future, but it was ready to enter only into organizational structures of the democratic popular orientation, similar to the Warsaw Populists, rallied around the Zarania. In addition to the Democrats, the Btok comprised Polish right and left political forces, united by antiRussian, anti-Prussian and legionary ideas. In it there were Populists zaraniazy, National Radicals - Radykaty narodowy, an ND group - Secesja Narodowo-Demokratyczna, which had split off from the party, led by Roman Dmowski and Zygmunt Balicki, but retained their Polish chauvinism. A section of the 'Realists,' having separated from the environment of the Petersburg newspaper Kraj and united into Grupa Pracy Narodowej, also belonged to the Bloc together with some other structures. ${ }^{38}$ That heterogeneity, most probably, caused the LDP's distrust of its political partner. Besides, the party's ties with the Labour group in the Russian Duma (Trudoviki) raised hopes for the achievement of Lithuania's political independence in case of revolution or military defeat of the Russian aggressive statehood. That must have conditioned the lack of activity in 'the Polish sphere'.

It is noteworthy that, despite the categorical orientation of the LDP towards the winning of Lithuanian statehood within ethnographic boundaries, the party programme directives sought the formation of civic society through the "broad democratic autonomy of ethnic Lithuania with the Seimas in Vilnius, elected in a universal, secret, direct and equal ballot without any discrimination of sex, religion, ori-

${ }^{36}$ M.Römcr. Dziennik, t. 4, 373.

${ }^{37}$ Ibid., t. 5, f. 138-2232, 6-7.

${ }^{38}$ Ibid., t. 4, 319, 320. 
gin or nationality ...". ${ }^{39}$ Further the programme stressed the importance of "the recognition and protection of the rights of other nations of Lithuania, so that they would feel no need to resist the aspirations of the Lithuanians and to separate from them ...". ${ }^{40}$ The Poles, as well as the other nations of the country concerned with the preservation of their national identity, were required "to do their duty to the country in a manner equal with the Lithuanians". ${ }^{41}$ Without a doubt, the LDP ideologues were aware that only the creation of civic society would prevent any national discrimination and create the conditions for the formation of the Lithuanian political nation.

Regrettably, things took a turn for the worse. Strong nationalist trends destroyed the democratic forces, which were guided by rational thinking. The values of the krajowcy (priority of historical consciousness and restoration of the historic state) were abused and rejected by the Polish aggressive nationalism (the 1920-1922 phenomenon of Litwa środkowa 'Central Lithuania'), while the LDP and the above-mentioned Lithuanian Social Democrats failed to resist the dictate the Lithuanian defensive nationalism. Plans for the formation of civic society had to be postponed and together with other political structures all the resources had to be mobilized for the implementation of the idea of a national state for the protection of the nation. The loss of Vilnius - its occupation by Poland in 1920 - determined the course of action of all the political forces in that direction and served as a permanent reminder that, in order to ensure the interests of the majority (the Lithuanians), it was necessary to neutralize the political and cultural danger of Polishness. In contrast to the hopes of Mykolas Römeris, that Vilnius would be "a capital and centre for all equally, a capital for peoples living together rather than a weapon to dominate cultural cooperation (or not) between the region's inhabitants, or an instrument to subdue others", ${ }^{42}$ the city was turned into a bone of contention.

${ }^{30}$ Lietuviu demokratu partijos programa. Tilžè, 1906, 7.

${ }^{40}$ L. V-kas [Kazys Grinius]. Apic šalies neprigulmybç. Varpas. nr. 3. 1914, 105.

${ }^{41}$ J. Bckampis [J. Stankcvičius]. Apie demokratų politiką. Lietuvos žinios, nr. 42, April 15 (28), 1915.

${ }^{42}$ M. Romer. Dziennik, t. 26, f. 138-2252, 187. 